\title{
SER DOCENTE NEGRO NA PÓS-GRADUAÇÃO EM COMPUTAÇÃO: DITOS E NÃO DITOS
}

\author{
Ecivaldo de Souza Matos ${ }^{1}$ \\ Juliana Maria Oliveira dos Santos ${ }^{2}$ \\ Emilayne Feitosa Corlett ${ }^{3}$ \\ Paloma Marques Ferreira de Jesus ${ }^{4}$ \\ Tatiana Cordeiro do Nascimento ${ }^{5}$
}

Resumo: Alguns estudos têm evidenciado o aumento na participação de negras e negros no ensino superior no Brasil. Sabe-se que esse aumento não é equitativo para todas as áreas de conhecimento. Este artigo apresenta alguns resultados de uma pesquisa piloto, cujo objetivo foi identificar elementos da trajetória de formação e de atuação de negras e negros na posição docente em programas/cursos de pós-graduação na área de Ciência da Computação no Brasil. Por meio de questionário e entrevistas, identificaram-se elementos qualitativos caracterizadores da trajetória acadêmica de professoras e professores negras e negros na Ciência da Computação, com a perspectiva de fomentar novos estudos sobre relações raciais e de gênero na Ciência da Computação; além de oferecer alguns subsídios para novas pesquisas e ações afirmativas voltadas ao aumento da população negra no quadro docente nos campos das ciências exatas no Brasil.

Palavras-chave: Raça; Computação; Pós-Graduação; Trajetória; Gênero.

\section{TO BE A BLACK TEACHER IN POSTGRADUATE COMPUTING: SAID AND NOT-SAIID}

Abstract: Some studies have shown an increase in the participation of blacks and blacks in higher education in Brazil. It is known that this increase is not fair for all areas of knowledge. This article presents some results of a pilot research, whose objective was to identify elements of the trajectory of training and performance of blacks who holds teaching position in postgraduate programs on Computer Science in Brazil. Through questionnaire and interviews, we identified qualitative elements that characterize the academic trajectory of black teachers in Computer Science. The intent and perspective is to foster further studies on race and gender relations in Computer Science; besides offering some subsidies for new

${ }^{1}$ Professor do Departamento de Ciência da Computação e do Programa de Pós-graduação em Ciência da Computação, Instituto de Matemática e Estatística da Universidade Federal da Bahia Salvador, Bahia, Brasil.E-mail: ecivaldo@ufba.br

${ }^{2}$ Estudante do curso de Bacharelado em Sistemas de Informação, Instituto de Matemática e Estatística da Universidade Federal da Bahia; Salvador, Bahia, Brasil.E-mail: juliana.maria@ufba.br

3 Estudante de Mestrado em Ciência da Computação no Instituto de Matemática e Estatística da Universidade Federal da Bahia, Salvador, Bahia, Brasil.E-mail: emilayne.corlett@ufba.br

${ }^{4}$ Estudante do curso de Bacharelado Interdisciplinar em Humanidades, Instituto de Humanidades, Artes e Ciências Milton Santos da Universidade Federal da Bahia, Salvador, Bahia, Brasil. E-mail: paloma_hsm@hotmail.com

5 Estudante do curso de Bacharelado em Gênero e Diversidade, Instituto de Filosofia e Ciências Humanas da Universidade Federal da Bahia, Salvador, Bahia, Brasil. E-mail: mel.cordeiro@hotmail.com 
researches and affirmative actions aimed at increasing the black population in the teaching profession in the fields of exact sciences in Brazil.

Key-words: Race; Computing; Postgraduate Studies; Trajectory; Genre.

\section{ÊTRE UN PROFESSEUR NOIR DANS LA POST-GRADUATION EN COMPUTATION: LE DIT ET LE NE PAS DIT}

Résumé: Certaines études ont montré une augmentation de la participation des Noirs et Noires à l'enseignement supérieur au Brésil. On sait que cette augmentation n'est pas équitable pour tous les domaines de la connaissance. Cet article présente quelques résultats d'une recherche pilote dont l'objectif était d'identifier des éléments de la trajectoire de formation et de performance des Noires et des Noirs occupant un poste professeur dans des programmes ou cours de post-graduation dans le domaine de Science de la Computation au Brésil. À travers d'un questionnaire et d'entretiens, on identifient des éléments qualitatifs que caractérisent de la trajectoire académique des enseignants noires et noirs en Science de la Computation, dans la perspective de favoriser de nouvelles études sur les relations raciaux et sexes en Science de la Computation; en plus d'offrir des subventions pour de nouvelles recherches et actions affirmatives visant à augmenter la population noire dans la profession enseignante dans les domaines des sciences exactes au Brésil.

Mots-clés: Race; Informatique; Post-Graduation; Trajectoire; Genre.

\section{SER DOCENTE NEGRO EN LA POSGRADUACIÓN EN COMPUTACIÓN: DITOS Y NO DITOS}

Resumen: Alguns estudios han evidenciado el aumento en la participación de negras y negros en la enseñanza superior en Brasil. Se sabe que este aumento no es equitativo para todas las áreas de conocimiento. Este artículo presenta algunos resultados de una investigación piloto, cuyo objetivo fue identificar elementos de la trayectoria de formación y de actuación de negras y negros en la posición docente en programas / cursos de postgrado en el área de Ciencia de la Computación en Brasil. Por medio de cuestionario y entrevistas, se identificaron elementos cualitativos caracterizadores de la trayectoria académica de profesoras y profesores negros y negros en la Ciencia de la Computación, con la perspectiva de fomentar nuevos estudios sobre relaciones raciales y de género en la Ciencia de la Computación; además de ofrecer algunos subsidios para nuevas investigaciones y acciones afirmativas dirigidas al aumento de la población negra en el cuadro docente en los campos de las ciencias exactas en Brasil.

Palabras-clave: Raza; Computación; Posgraduación; Trayectoria; Género.

\section{INTRODUÇ̃̃̃O}

A população total no Brasil em 2015 foi estimada em 204,8 milhões de pessoas, das quais $45,1 \%$ se declararam de cor parda, $45,2 \%$ de cor branca e $8,9 \%$ de cor preta, totalizando $54 \%$ de pessoas negras (IBGE, 2016). Ainda assim, os dados apresentados pela Pesquisa Nacional por Amostra de Domicílios (PNAD) revelam forte disparidade entre a população branca e a negra em vários indicadores educacionais. 
Na rede pública de ensino superior, o aumento da participação de pretos e pardos entre aqueles que frequentavam cursos de graduação foi bem menor que na rede privada (IPEA, 2014), conforme indicado no Gráfico 1. Possivelmente esse aumento decorreu da implantação de algumas políticas de acesso à educação superior, como o Programa Universidade para Todos (ProUni), critérios de seleção que consideram a renda familiar per capita e as cotas étnico-raciais.

Gráfico 1. Participação de brancos e pretos/pardos no total de pessoas que frequentavam cursos de graduação nas redes pública e privada no Brasil [20052012 - em \%]

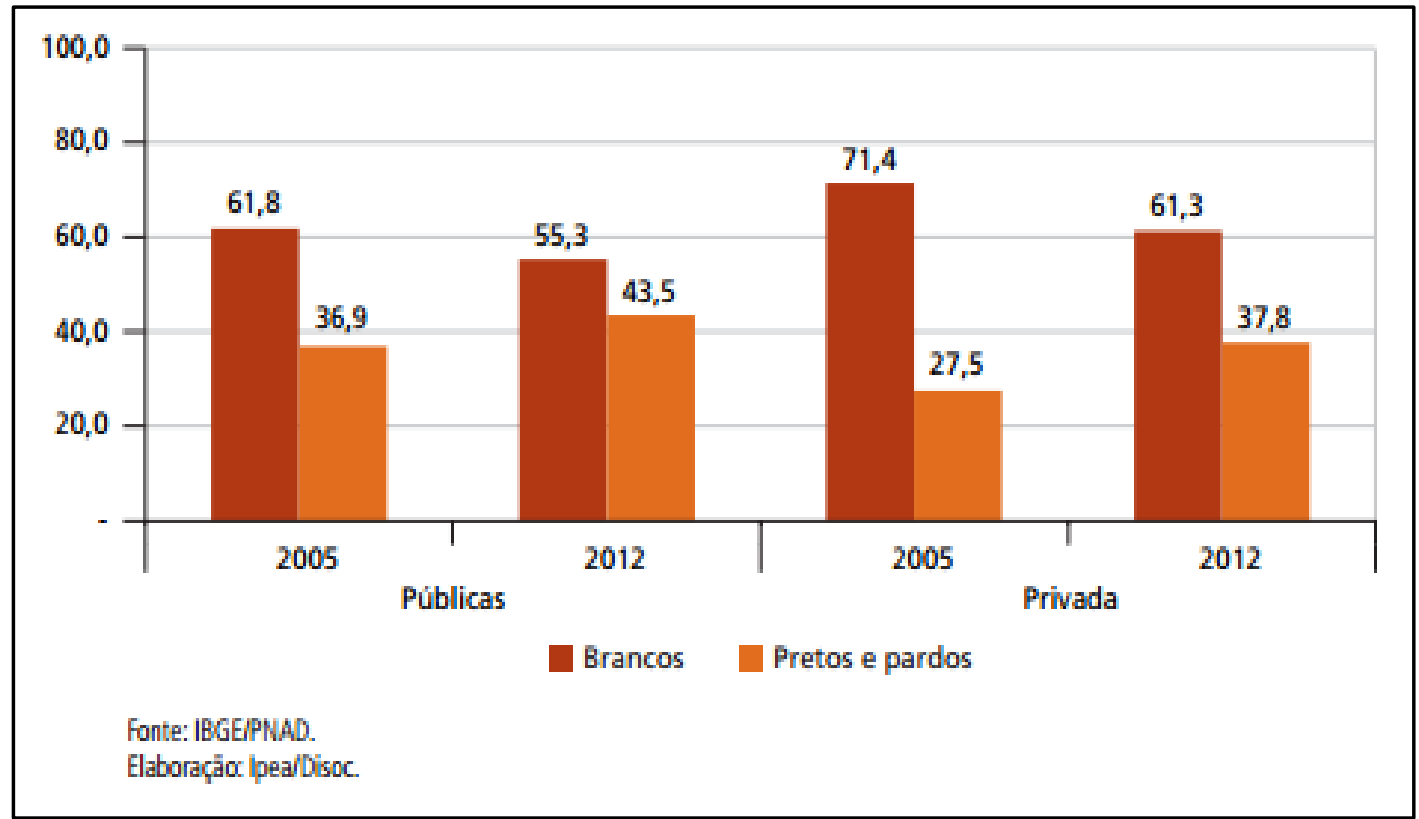

Fonte: IPEA (2014).

Ainda que existam indicativos de avanços decorrentes da implementação de políticas afirmativas de acesso à educação superior, é fato que a baixa proporção de negras e negros a concluir o ensino médio continua a ser um entrave à equalização do acesso entre negras(os) e brancas(os) (IPEA, 2014).

Segundo Margolis et al. (2017), nos Estados Unidos, o número de afroamericanos e latinos que recebem diplomas de graduação em Ciência da Computação é proporcionalmente baixo quando comparados a outras etnias. No Brasil, as políticas de ações afirmativas para a pós-graduação têm permitido acesso de muitos jovens negras e negros à universidade. Mas a permanência e o desempenho deles nos cursos de exatas, inclusive nos cursos de graduação em Computação (Bach. em 
Ciência da Computação, Licenciatura em Computação e Bach. em Sistemas de Informação), têm sido um desafio cotidiano (Takahashi; Saldaña; Soares, 2017).

A formação científica na área de Computação é fator estratégico para todos os países. No Brasil, o documento de área ${ }^{6}$ (Ciência da Computação) da Coordenação de Aperfeiçoamento de Pessoal de Nível Superior (Capes), norteador e sintetizador da avaliação da pós-graduação, sinaliza para a importância (e valorização) da pesquisa por equipes multidisciplinares como uma forma importante para obtenção de resultados científicos úteis à sociedade, indicando ações de sensibilização para problemas inerentes à pesquisa inter e multidisciplinar, além de valorizar iniciativas que busquem sair dos limites tradicionais da Computação, como aquelas relacionadas a estudos de gênero e de raça.

Nesse sentido, faz-se necessário e urgente iniciar uma pauta de pesquisa que busque conhecer e reconhecer o universo de pesquisa em Ciência da Computação, buscando entender como as dinâmicas sociais interferem no seu desenvolvimento e sobretudo como atuar para estabelecer políticas de equidade raça/etnia no campo da Ciência da Computação e em outras Ciências Exatas.

Dada a pluralidade de potenciais questões para investigação acerca desse tema, este artigo apresenta alguns dos resultados de uma pesquisa piloto, apoiada pelo Edital do Concurso de Pesquisa Negras e Negros nas Ciências promovido pela Fundação Carlos Chagas $^{7}$ com recursos da Ford Foundation ${ }^{8}$.

O objetivo desta pesquisa foi identificar elementos da trajetória de formação e de atuação de negras e negros na posição docente em programas/cursos de pósgraduação na área de Ciência da Computação.

\section{NEGRAS E NEGROS NAS CIÊNCIAS EXATAS}

Esse excerto indica a imagem clássica de cientista inscrita em nosso imaginário social, mas não somente nele. Adiciona-se a esse perfil, tubos de ensaio,

\footnotetext{
${ }^{6}$ Disponível em: <http://www.avaliacaotrienal2013.capes.gov.br/documento-de-area-e-comissao $>$. Acesso em: 27 jul. 2018.

${ }^{7}$ Disponível em: <http://www.fcc.org.br/fcc/negras-e-negros-nas-ciencias/apresentacao>. Acesso em 27/07/2018.

${ }^{8}$ Disponível em: <https://www.fordfoundation.org/>. Acesso em: 27/07/2018.
} 
cabelos arrepiados e substâncias coloridas. Para além de um imaginário coletivo, esse perfil se materializou durante muitos anos nas ciências.

Segundo Lima (2002), "as universidades continuam a reproduzir o androcentrismo e a representar seus espaços como masculinos, principalmente em se tratando da pesquisa, da direção e da administração institucional [...]” (p. 53). O percurso para a presença de mais homens e mulheres (negros e negras) no ensino superior passa fundamentalmente por um conjunto de políticas de ações afirmativas para ingresso e permanência. Deixadas (por enquanto) à parte as avaliações sobre a qualidade dessas políticas, faz-se necessário destacar a política de reserva de vagas nas universidades públicas e, adoção do Exame Nacional do Ensino Médio (Enem ${ }^{9}$ ) e do Sistema de Seleção Unificada $\left(\operatorname{Sisu}^{10}\right.$ ) como mecanismos de seleção e acesso à educação superior pública.

Dentre um conjunto de políticas de acesso e permanência, as universidades federais implementaram sistemas de cotas e bonificações (Maia, 2007). Diversos estudos discutem a validade dessas políticas para a efetividade de acesso e permanência de pessoas historicamente fora do cenário acadêmico e da formação de nível superior no Brasil (Silva; Negrão, 2012; Bevilaqua, 2015; Araújo, 2001; Bittar; Almeida, 2006).

Nesse sentido, a Ford Foundation (Fundação Ford), em parceria com a Fundação Carlos Chagas (FCC), executaram o Programa Internacional de Bolsas de Pós-graduação da Fundação Ford (IFP - Programa Bolsa) (Rosemberg, 2013). O Programa Bolsa foi implementado em 12 países, tendo durado 11 anos no Brasil (2002-2013). Um dos objetivos desse programa foi contribuir para que um conjunto de pessoas provenientes de grupos sociais pouco representados no ensino superior pudessem estudar e se preparar para, dentre outros objetivos explícitos ou implícitos, se fazer representar nos espaços acadêmicos e de decisão no país (Rosemberg, 2013).

Ainda assim, no imaginário da população temos a pessoa que desenvolve ciência como uma construção simbólica do homem branco e aburguesado. Todavia, ao investigar mais a fundo, percebe-se outro aspecto ainda latente, a dicotomização de áreas pelo gênero. Segundo Lima (2002), “a maioria masculina está concentrada

\footnotetext{
${ }^{9} \mathrm{https}$ ://enem.inep.gov.br

${ }^{10} \mathrm{http}: / /$ sisu.mec.gov.br/
} 
nas ciências agrárias, exatas, sociais, engenharia e computação, enquanto a maioria feminina está nas ciências biológicas, da saúde, humanas, letras e artes” (p. 54, grifo nosso). No campo da Ciência da Computação, a experiência cotidiana mostra que, apesar do universo de estudantes ter-se modificado ao longo dos anos, a presença está longe de ser equitativa, seja no tocante aos gêneros, seja no tocante às raças/etnias.

\section{A CIÊNCIA DA COMPUTAÇÃO NO BRASIL}

Em 1967, a Pontifícia Universidade Católica do Rio de Janeiro (PUC-Rio) funda o que até então parece ser o primeiro departamento de Computação em uma universidade brasileira (PUC-RIO, 2000). Todavia, a Universidade Federal da Bahia (UFBA) foi pioneira ao iniciar as atividades do primeiro curso de graduação na área de Computação instalado em março de $1969^{11}$, intitulado Bacharelado em Processamento de Dados (atual Bacharelado em Ciência da Computação) no então Departamento de Processamento de Dados (DPD) do Instituto de Matemática (UFBA, 2018b). O Instituto nesse período (1968-1971) estava sob a direção de uma mulher, a Profa. Lolita Carneiro de Campos Dantas (UFBA, 2018a).

Na pós-graduação, de acordo com os dados fornecidos pela Capes, o primeiro curso de pós-graduação em Computação no Brasil foi reconhecido e teve início no ano de 1967 na PUC-Rio, no Departamento de Matemática. No cenário das instituições públicas de ensino, está o Instituto Militar de Engenharia (IME) como protagonista nesse processo, seguido pelas Universidade Federal do Rio Grande do Sul (UFRGS) e Universidade Federal de Campina Grande (UFCG), que deram início ao Mestrado em Ciência da Computação no ano de 1973.

Segundo o documento de área (Ciência da Computação) da Capes, em setembro de 2017 contabilizaram-se 77 programas de pós-graduação, com 64 cursos de mestrado acadêmico, 34 de doutorado e 11 de mestrado profissional ${ }^{12}$. Todavia,

\footnotetext{
${ }^{11}$ Conforme a Universidade Estadual de Campinas (Unicamp) (2000), o primeiro curso de graduação em Ciência da Computação no Brasil foi iniciado pela Unicamp em 1969, mas o curso da UFBA foi instalado em 08 de março de 1969, conforme registros do sistema e-MEC, disponível em http://emec.mec.gov.br/emec/consulta-

cadastro/detalhamento/d96957f455f6405d14c6542552b0f6eb/NTc4/c1b85ea4d704f246bcced664fdae ddb6/Q0nKTkNJQSBEQSBDT01QVVRBx8NP. Acesso em: 31 jul. 2017.

${ }^{12}$ Informações coletadas no Relatório de Avaliação Quadrienal 2017. Disponível em: https://docs.google.com/viewer?a=v\&pid=sites\&srcid=Y2FwZXMuZ292LmJyfGF2YWxpYWNhbyl xdWFkcmllbmFsfGd4OjcyMGE2NGRiYTkzMmEzNTY. Acesso em: 20 set. 2017.
} 
nem todos os cursos de pós-graduação stricto sensu em Computação estão submetidos à área de avaliação Ciência da Computação na Capes. Há cursos nas áreas Interdisciplinar e Engenharias IV.

Muitos são os desafios de ser professor(a) negro(a) em um departamento ou em um programa de pós-graduação e, além disso, exteriorizar preocupações para além dos limites epistemológicos disciplinares das ciências exatas, especialmente nas ciências historicamente mais prestigiadas, como as Engenharias, de onde a Ciência da Computação possivelmente herdou o seu pseudo-prestígio.

\section{NEGRAS E NEGROS NA COMPUTAÇÃO: ATENÇÃO NECESSÁRIA}

Desde os primórdios da colonização, o acesso à educação se estruturou de forma diferenciada em relação aos diversos grupos sociais. Nos estudos de História da Educação, predomina a ideia de que a população negra escravizada ou "livre" não teve acesso ao sistema educacional.

No decorrer da década de 1930, a criação do Ministério da Educação e Cultura (MEC) e da política nacionalista de Getúlio Vargas transformou a educação em assunto de segurança nacional. Nesse período, com a expansão da indústria e da urbanização, novas demandas educacionais forçaram o governo a ampliar a rede de ensino, incluindo as escolas técnicas e profissionais. Nesse contexto, podemos identificar o surgimento de mobilizações da população negra e a criação de organizações que começam a pautar em suas lutas questões relacionadas à educação, como enfatiza Domingues (2007):

É por intermédio das múltiplas modalidades de protesto e mobilização que o movimento negro vem dialogando, não apenas com o Estado, mas principalmente com a sociedade brasileira. A trajetória desse movimento vem se caracterizando pelo dinamismo, pela elaboração e reelaboração, em cada conjuntura histórica, de diversas estratégias de luta a favor da integração do negro e erradicação do racismo na sociedade brasileira. (p. 126)

Esse contexto histórico da luta por igualdade racial evidencia a força do movimento negro em toda parte do Brasil; e endossa as lutas em prol da presença negra nas instituições de ensino e no combate à discriminação, fazendo surgir mecanismos de valorização dos descendentes de africanos. 
Segundo dados do Ipea (2014), após adoção de políticas de ação afirmativa pelas universidades públicas, a presença de estudantes negras(os) nos cursos de graduação aumentou. Mas essa mudança não tem sido necessariamente equitativa entre as áreas de conhecimento, conforme os dados apresentados pelo IBGE sobre pessoas graduadas ou tituladas no mestrado/doutorado no Brasil, considerando o Índice de Paridade de Gênero (IPG) e o Índice de Paridade Racial (IPR). As Ciências Matemáticas e de Computação estão muito aquém das Ciências Humanas, da Educação e da Saúde. Todavia, no tocante à pós-graduação, não há estudos conclusivos sobre a participação de negras e negros no corpo docente de programas de pós-graduação em Ciência da Computação (IPEA, 2014).

\section{METODOLOGIA DE PESQUISA}

Como informado, o objetivo desta pesquisa foi identificar elementos da trajetória de formação e de atuação de negras e negros na posição docente em programas/cursos de pós-graduação na área de Ciência da Computação.

Nesse sentido, dada a natureza do objeto de investigação, essencialmente descritivo-analítico, foram utilizadas duas técnicas para coleta de dados (em duas etapas): (i) questionário e (ii) entrevista.

O questionário foi concebido e disponibilizado na plataforma Google Forms $^{13}$, escolhida por proporcionar oportunidade de trabalho colaborativo entre a equipe, por facilitar a organização dos dados para futuras análises, por ser uma plataforma personalizável e possuir opções de perguntas de múltipla escolha a listas suspensas e escalas lineares.

Os participantes poderiam responder até 55 perguntas, em sua maioria objetivas (múltipla escolha), acerca de cor/raça, gênero e região, além de perguntas sobre elementos que motivaram a escolha dessa área, sobre desafios superados e a superar, participação em programas de ação afirmativa, racismo, homofobia.

Para validação das questões de acordo com as variáveis de pesquisa foi executado pré-teste com alguns sujeitos, selecionados por conveniência. Após o préteste, o questionário foi ajustado e seguiu para divulgação e disponibilização pública.

\footnotetext{
${ }^{13}$ Serviço oferecido pela Google ${ }^{\circledR}$ LLC.
} 
Anterior à divulgação do questionário foi realizado um levantamento de cursos stricto sensu em funcionamento no Brasil por meio da Plataforma Sucupira/Capes (Dados Cadastrais do Programa). Para isso foram selecionadas as opções de Área de Avaliação (Ciência da Computação, Engenharias IV e Interdisciplinar) e Situação do Programa (em funcionamento), conforme apresentado no Quadro 1.

Quadro 1. Filtros utilizados, número de cursos retornados e totais de contatos realizados em cada área

\begin{tabular}{|c|c|c|c|}
\cline { 2 - 4 } \multicolumn{1}{c|}{} & Pesquisa 1 & Pesquisa 2 & Pesquisa 3 \\
\hline Área de Avaliação & $\begin{array}{c}\text { Ciência da } \\
\text { Computação }\end{array}$ & Engenharias IV & Interdisciplinar \\
\hline $\begin{array}{c}\text { Situação do } \\
\text { Programa }\end{array}$ & Em funcionamento & Em funcionamento & Em funcionamento \\
\hline $\begin{array}{c}\text { Número de } \\
\text { programas }\end{array}$ & 81 & 90 & 346 \\
\hline Contatos realizados & 81 & 90 & 60 \\
\hline
\end{tabular}

Fonte: elaboração própria.

Além dos programas da Área de avaliação "Ciência da Computação" e "Engenharias IV", analisamos os objetivos dos programas da área Interdisciplinar quanto a sua pertinência à Ciência da Computação, cujos cursos focalizem aspectos interdisciplinares da Computação, como Informática na Educação, Modelagem Computacional, entre outros. A partir dessa análise, foram selecionados 60 programas da área Interdisciplinar.

Ao finalizar essa etapa, buscaram-se os contatos (telefones e e-mails) dos programas na Plataforma Sucupira. Aqueles que não possuíam e-mail cadastrado na plataforma, tiveram seus endereços eletrônicos encontrados nos respectivos websítios institucionais para divulgação do questionário.

Além da divulgação direta aos programas de pós-graduação, o questionário foi divulgado nas listas eletrônicas da Sociedade Brasileira de Computação (SBC), da Universidade Federal da Bahia, no websítio da Associação Nacional de Pósgraduação e Pesquisa em Educação (ANPEd), nas redes sociais Facebook ${ }^{\circledR 14}$ e Twitter $^{\mathbb{C 1 5}}$; e no website do Grupo de Pesquisa e Extensão Onda Digital

\footnotetext{
${ }^{14} \mathrm{http}: / /$ www. facebook.com/ProgramaOndaDigital/

${ }^{15} \mathrm{http}: / /$ twitter.com/ondadigitalufba
} 
$(\mathrm{UFBA} / \mathrm{CNPq})^{16}$. O questionário ficou disponível entre 3 de julho e 7 de agosto de 2016 e recebeu 49 respostas. A maioria dos respondentes, cerca de $65 \%$, estava na faixa etária entre 30 e 45 anos, conforme apresentado no Gráfico 2.

\section{Gráfico 2. Percentual de respostas ao questionário por idade}

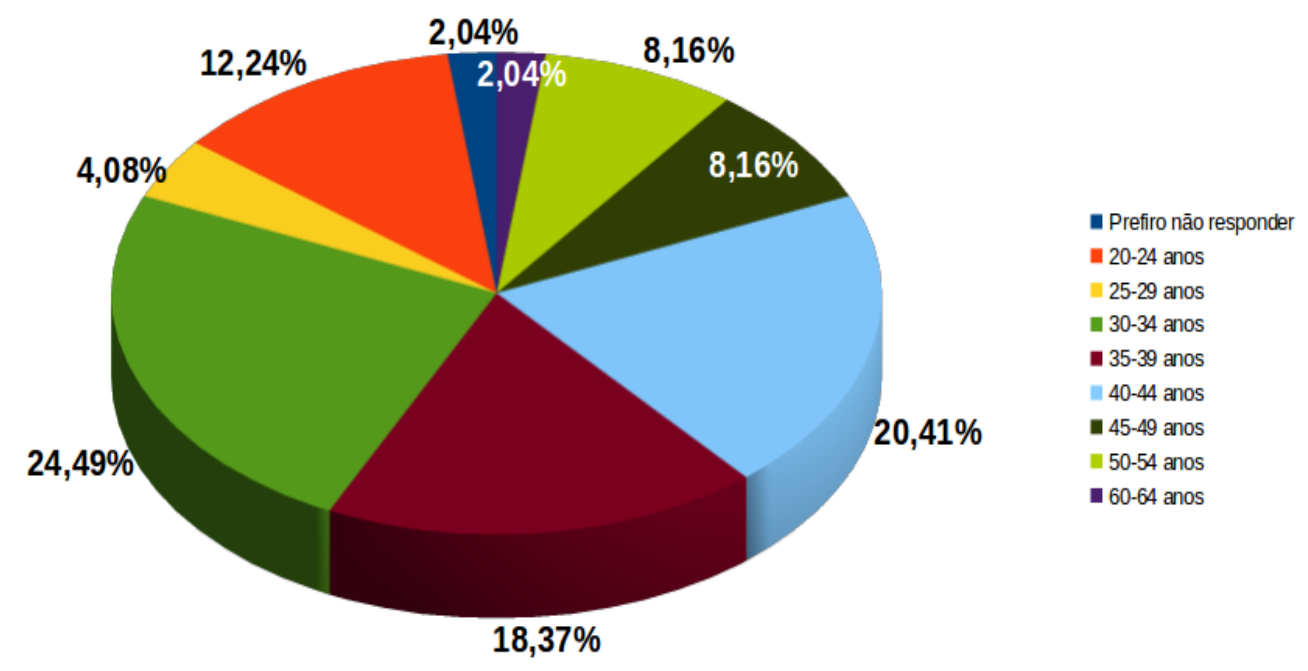

Fonte: Elaboração própria.

As entrevistas de caráter semiestruturado foram realizadas na segunda etapa da pesquisa, apenas com aquelas(es) que durante o preenchimento do questionário se dispuseram a contribuir com mais dados para a pesquisa. Todas as entrevistas foram gravadas e transcritas.

$\mathrm{Na}$ etapa de entrevistas, buscou-se aprofundar a percepção sobre a trajetória e atuação de algumas(ns) dessas(es) professoras(es) negras(os) na carreira acadêmica em Ciência da Computação, na busca por elementos não identificados no questionário e/ou esclarecimento de pontos que merecessem mais detalhamento.

Salientamos que tentamos buscar dados de gênero e raça, autodeclarados pelos pesquisadores, junto ao $\mathrm{CNPq}$ (Plataforma Lattes), para avaliação quantitativa sobre a presença de negras e negros nos estudos acadêmicos na Ciência da Computação, porém sem sucesso.

\section{CUIDADOS ÉTICOS}

\footnotetext{
16 http://www.ondadigital.ufba.br
} 
Para participar da pesquisa, foi preciso que os sujeitos confirmassem o consentimento para uso anônimo de seus dados, por meio do Termo de Consentimento Livre e Esclarecido (TCLE). Nesse documento havia explicações acerca da natureza da pesquisa e do local de realização; informações sobre os pesquisadores e financiadores, objetivos, contatos, sigilo da identidade; e esclarecimentos sobre a voluntariedade da participação.

Foram produzidos dois TCLE. O primeiro - eletrônico - foi encaminhado junto com o questionário. O segundo foi entregue (e colhido) impresso ou digitalizado no momento da entrevista, apenas para os sujeitos selecionados e que aceitaram participar dessa etapa da pesquisa. Esses documentos estão devidamente armazenados sob poder dos pesquisadores. Todos os sujeitos indicados neste artigo consentiram o uso dos seus dados por meio dos TCLE.

\section{OS PRIMEIROS RESULTADOS: OS DITOS}

O questionário ficou disponível para coleta de respostas por 36 dias e recebeu 49 contribuições de pessoas de 13 estados do Brasil (Gráfico 3), sendo 21 mulheres e 28 homens.

\section{Gráfico 3.}

\section{Percentual de Respostas por UF}

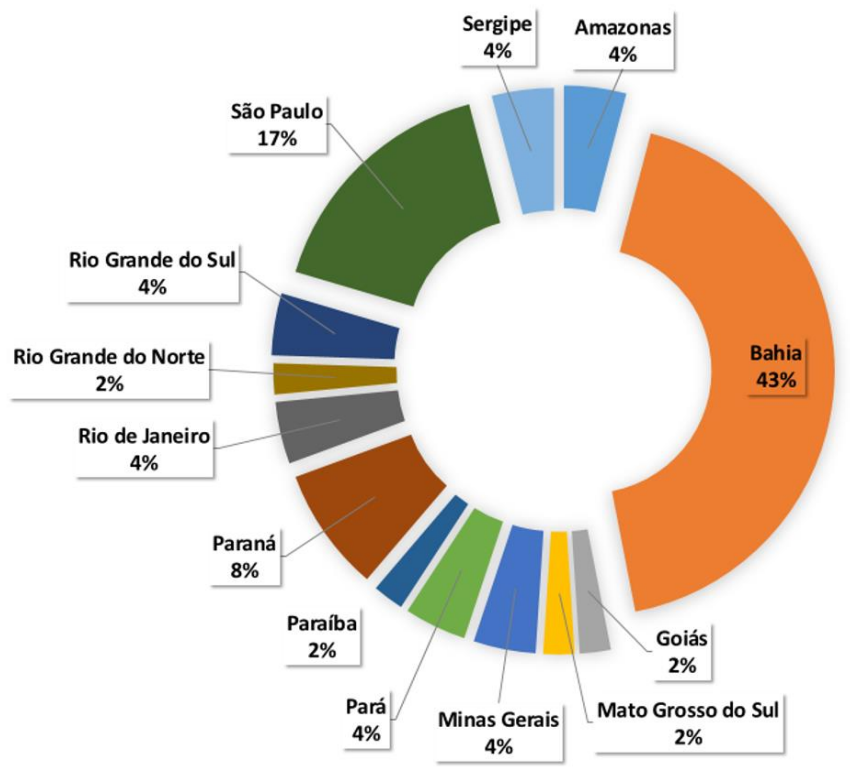

Fonte: Elaboração própria. 
A abordagem quanto ao pertencimento étnico-racial dos participantes foi realizada por meio de duas perguntas: "Você se considera negra(o)?", com opções de resposta "Sim", "Não" e "Não sei responder"; e "Qual é a sua cor/raça?", com opções de resposta em consonância com as categorias censitárias "Amarela", "Branca", "Indígena", "Parda", "Preta" e "Não sei responder". Entre os respondentes 14 se autoclassificaram brancos, 3 amarelos, 18 pretos e 14 pardos. Dentre as pessoas de cor parda, 2 não souberam responder se são negras; 3 responderam que não se consideram negras e 9 se consideram negras (Gráfico 4).

Entendemos que a identidade racial constitui a identidade global do indivíduo, assim como a sua identidade docente, e está relacionada à sua autoestima e como ela(e) se vê na relação com os outros. Conforme Ferreira (2000), a desqualificação social histórica e sistemática tem levado a representações sociais de valores e sentimentos negativos relacionados aos negros. Como afirmam Oliveira e De Rose (2015, p. 83), “o afrodescendente desde cedo 'aprende', mediante mecanismos eficazes de reprodução ideológica, que a identidade positivamente construída é a do "branco"”. Isso talvez explique porque 36\% dos sujeitos que se consideram pardos responderam que não se consideram negros ou não sabem responder.

\section{Gráfico 4.}

\section{Cor/Raça das pessoas que responderam}

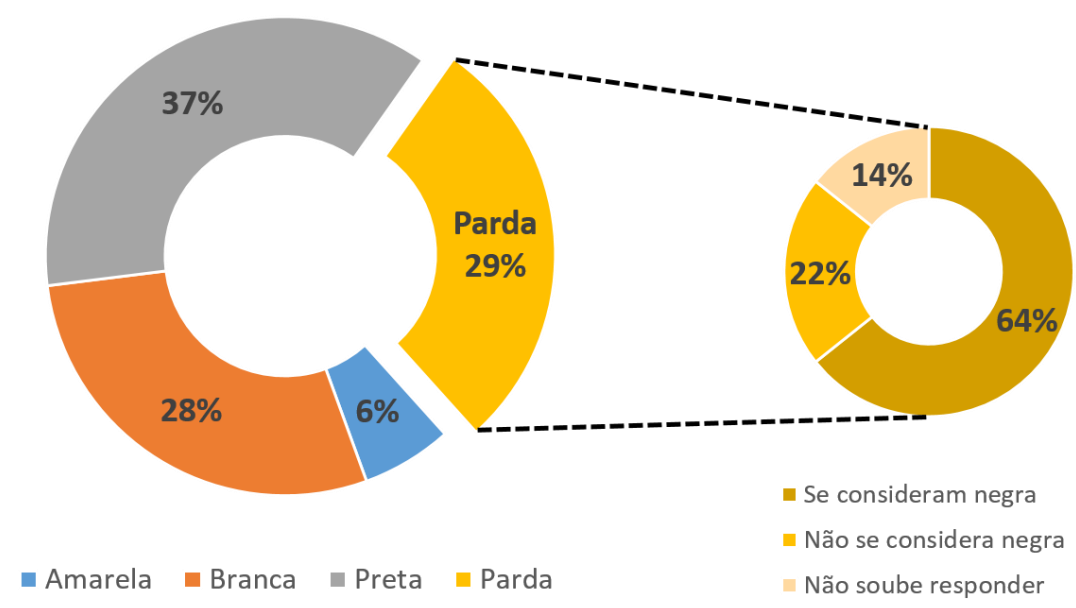

Fonte: Elaboração própria. 
Nesta pesquisa consideramos como negros aqueles que se autodeclararam como pardos e pretos (32 participantes). Além disso, para efeitos de análise, foram considerados apenas professoras(es) que atualmente lecionam/orientam em algum curso de pós-graduação stricto sensu em Computação no Brasil, resultando em 11 participantes, cujos perfis estão resumidos no Quadro 2. Esses participantes foram convidados à etapa de entrevista, mas apenas cinco aceitaram participar (sujeitos $\mathrm{A}$, D, E, G e I - marcados no Quadro 2).

\section{Quadro 2. Perfil resumido dos sujeitos selecionados com destaque àqueles} participantes da etapa de entrevista

\begin{tabular}{|l|l|l|l|l|}
\hline Sujeito & Gênero & Cor/raça & Região & Faixa etária \\
\hline A & Feminino & Preta & Sudeste & 60 a 64 anos \\
\hline B & Feminino & Parda & Sudeste & 30 a 34 anos \\
\hline C & Feminino & Preta & Sudeste & 50 a 54 anos \\
\hline D & Feminino & Parda & Nordeste & 45 a 49 anos \\
\hline E & Feminino & Parda & Nordeste & 45 a 49 anos \\
\hline F & Masculino & Pardo & Nordeste & 40 a 44 anos \\
\hline G & Masculino & Preto & Nordeste & 35 a 39 anos \\
\hline H & Masculino & Preto & Nordeste & 30 a 34 anos \\
\hline I & Masculino & Preto & Nordeste & 35 a 39 anos \\
\hline J & Masculino & Preto & Nordeste & 35 a 39 anos \\
\hline K & Masculino & Preto & Nordeste & 40 a 44 anos \\
\hline
\end{tabular}

Fonte: Elaboração própria.

\section{ALGUNS DADOS DOS SUJEITOS SELECIONADOS COLETADOS POR MEIO DO QUESTIONÁRIO}

Nesta seção apresentaremos alguns dados dos 11 sujeitos convidados para a entrevista, ou seja, aqueles que se adequaram ao perfil buscado, professoras(es) negros em atuação em curso de pós-graduação stricto sensu em Ciência da Computação, sumarizados dentre os coletados por meio do questionário. Esses dados foram classificados e serão apresentados por meio das categorias de análise. $\mathrm{Na}$ seção seguinte, esses dados serão discutidos, por meio de interlocução com os dados advindos das entrevistas. 


\section{$\underline{\text { Sobre a escolha da carreira }}$}

Dentre as possibilidades de resposta quando questionados sobre os porquês da escolha da Computação enquanto carreira, a maioria indicou que escolheu o curso por ter aptidão com matemática (dentre outras opções). Todavia, quatro deles (dois homens e duas mulheres) não indicaram a aptidão matemática como um dos motivos de escolha pela carreira; esses indicaram que a escolha ocorreu por já terem interesse na área, ter um amigo negro que trabalhava com computação, para ascensão social ou pela escassez de outros cursos de graduação na sua região. Apenas um dos sujeitos respondeu que fez a opção por ser mulher e entender, no momento de escolha, que essa profissão também é feminina. Dos onze sujeitos, apenas três indicaram dentre os motivos de escolha conhecer outros negros profissionais da área.

Aqueles que já possuíam interesse na área ou que a escolheu por recomendação familiar, informaram que, em seu período pré-acadêmico (antes de ingressar na graduação), não pensaram em fazer um curso diferente da computação. Os demais indicaram que passaram por várias outras possibilidades de escolha.

\section{$\underline{\text { Sobre dificuldades financeiras }}$}

Quase todos indicaram alguma dificuldade financeira durante a graduação; dois deles chegaram a interromper o curso por causa disso. Outros não indicaram essa dificuldade, mas informaram que exerceram trabalho remunerado durante a graduação.

\section{Sobre a discriminação}

No tocante à discriminação/preconceito, cinco sujeitos indicaram que sofreram algum tipo de discriminação ou preconceito por conta da sua cor/raça/etnia no ambiente acadêmico durante a graduação (no Brasil). Durante a pós-graduação, três passaram por situações ou ações discriminatórias ou preconceituosas pela cor/raça/etnia; cinco relataram passar por esses problemas em seu ambiente de trabalho. Todos aqueles que indicaram ter sofrido preconceito/discriminação em ambiente acadêmico durante a graduação informaram que passam(ram) pelos mesmos problemas durante a sua atividade profissional. Quase todos pensam ou pensaram em desistir da área, mas não indicaram ser pela discriminação, mas por dificuldades financeiras ou condições de trabalho consideradas por eles inadequadas. 
Quando questionados sobre terem vivenciado ou presenciado alguma cena de racismo no cotidiano acadêmico no contexto da Computação, quase todos ( 8 dos 11 sujeitos) indicaram já terem presenciado/vivenciado ou já saber de atos racistas nesse contexto. Dentre esses atos, um que se sobressaiu foi o questionamento sobre a capacidade do professor por parte dos estudantes por causa de sua cor/raça.

Por meio da entrevista foi possível coletar elementos mais precisos de como se configuram(raram) algumas dessas ações racistas, seja com ações circunscritas ao ambiente acadêmico ou fora dele, mas com relação direta na formação do sujeito enquanto estudante.

Outra coisa também que se falava muito no Rio, na época que eu era [...] quando eu comecei, ai fui fazer cientifico e tal, as outras empregadas em volta da minha mãe, elas olhavam e falavam para mim: "ah, você vai estudar né, então você vai arrumar um homem branco, não casa com negro, porque aí você melhora a raça. E você tem condição de casar com um homem branco porque você tem futuro e tal. Sujeito A

No tocante à discriminação pela orientação sexual, cinco sujeitos informaram ter notícias de atos homofóbicos no âmbito acadêmico da Computação, ainda que não tenham eles próprios presenciado ou vivenciado.

\section{$\underline{\text { Sobre bolsas de estudos }}$}

Apenas um dos entrevistados não teve bolsas de estudo na pós-graduação (mestrado e doutorado). Todavia, ele precisou trabalhar para manter os estudos durante todo o período em que cursou a pós-graduação, sendo necessário em algum momento interromper os estudos por dificuldades financeiras. Hoje ele é professor de uma universidade pública e não considera que isso tenha sido um empecilho na sua formação, conforme entrevista.

Apenas um dos 11 sujeitos participou de algum sistema de cotas ou programa de ação afirmativa durante a pós-graduação.

\section{Colegas negros}

A maioria (7 dos 11 sujeitos) indicou ter tido colegas negros durante a graduação; todavia, somente três lembraram de professores negros em seus cursos de pós-graduação.

\section{Sobre a área de atuação e colocação profissional}


Todos os sujeitos considerados lecionam na graduação e na pós-graduação em universidade pública como servidores públicos federais ou estaduais. Ainda que haja programas com pesquisas em Computação em diferentes áreas de avaliação da Capes, os sujeitos considerados participam como docentes permanentes em programas de pós-graduação avaliados pela área de Ciência da Computação na Capes.

\section{ENTENDENDO ALGUNS DADOS: AS ENTREVISTAS}

Dos 11 sujeitos selecionados e convidados para entrevista, apenas cinco aceitaram o convite, sendo três mulheres e dois homens. Considerando uma amostra por conveniência, foi possível realizar entrevistas remotas e presenciais ao longo dos meses de setembro e outubro de 2016. Foram entrevistados os sujeitos A, D, E, G e I, indicados no Quadro 2.

Algumas categorias de análise foram definidas a priori, outras surgiram a partir da literatura, especialmente a partir dos estudos de Margolis et al. (2017) e dos próprios dados coletados com os entrevistados. As falas que mais se sobressaíram nas entrevistas foram organizadas nas seguintes categorias: (1) professores como agentes de mudança; (2) mudanças na vida pela educação; (3) acesso à educação escolar; (4) permanência dos estudantes em condições sociais e econômicas desfavoráveis; (5) motivação de pais, familiares ou outras pessoas para os estudos; (6) (não) percepção ou afetividade do desrespeito, preconceito e a discriminação; (7) (não) percepção ou afetividade da reprodução de ações racistas por professores; (8) oportunidades existentes na trajetória; (9) (não) percepção ou afetividade da estereotipação nos ambientes acadêmico ou profissional na trajetória (questão de inteligência); (10) influência de pais, familiares ou outras pessoas na escolha de carreira; (11) (não) percepção ou afetividade do desrespeito, preconceito e discriminação; (12) contribuições para garantias de espaços para o negro na sociedade e na universidade; (13) (não) percepção ou afetividade da desigualdade profissional (representatividade do negro na universidade); (14) (não) percepção ou afetividade da estereotipação nos ambientes acadêmicos ou profissionais na atuação; (15) área de pesquisa; (16) (não) reconhecimento de pessoas negras na trajetória acadêmica e profissional; (17) participação feminina; (18) dificuldades ou facilidades na trajetória acadêmica; (19) 
circunstâncias que influenciaram na escolha da carreira; (20) percepção da adaptação ou acolhimento no meio acadêmico.

Nenhum dos sujeitos entrevistados (cinco de onze convidados) estavam entre os sujeitos pardos que não se consideram ou não sabia que eram negros. Por isso, não foi possível estabelecer discussão acerca da identidade racial desses sujeitos. Os demais apresentaram, tanto no questionário quanto na entrevista, a sua ideia de pertencimento racial negro, como indica o excerto abaixo:

Sim, não, na minha turma em particular só tinha mais uma pessoa é [...] e no curso todo assim, que eu me recordo agora talvez mais umas quatro ou cinco pessoas assim, no curso todo né, pessoas de outros períodos. (grifo nosso) Sujeito I

A categoria "professores como agentes de mudança" reflete a importância dos professores na trajetória dos entrevistados, no início da vida escolar e ao longo de toda a história de estudos. A influência positiva desses profissionais nas escolhas dos estudantes, a colaboração no direcionamento do discente são fatores que consequentemente transformaram a realidade dos entrevistados.

E ai eu fui pedir pro professor cartas de recomendação e ele me perguntou "porque você não vai fazer doutorado fora?" eu falei, "aaah, doutorado fora é coisa para rico. Eu vou fazer doutorado fora?" e ele "ah, não mas uma mulher só que consegue bolsa do cnpq, não sei o quê, blablabla, porque não tentar?". Eu fiquei meio assim e tal... É. Fui falar ainda com um professor no <omitido> também que era estrangeiro, perguntando para ele como é que era e ele "não, vai sim" e me incentivou, "vai fazer fora". Ai eu falei "bom, não custa tentar né...". Eu tentei, me aceitaram, eu falei é, vou... Suj eito A

São poucas as lembranças de professores ou colegas negros durante a sua trajetória acadêmica até os dias atuais, como indicado pelos Sujeitos A, D e I. A fala do Sujeito I, inclusive, levanta a sua dúvida quanto à identidade racial dos seus colegas/alunos, possivelmente baseado em aspectos fenotípicos, citados pelo Sujeito I como "a característica [de negro]".

Significativo não [sobre a presença de negros na pós graduação em computação]. Já tem um pouco mais, mas assim, já começa a aparecer alguns, mas não tem. E assim, é impressionante isso no Brasil porque você sai, você vai pros Estados Unidos, Inglaterra, onde você em principio vê que a discriminação é maior, mas tem muito mais alunos negros. [...] E bom, eu já participei de vários concursos, organizei alguns porque eu já fui chefe de departamento e tal, organizava. Não tinha candidatos negros. Não tinha. (grifo nosso) Sujeito A 
É...sim tenho, mas você perguntou se se consideravam negros? Bom, eu eu considerava negro, mas a gente nunca tinha uma conversa, eu considerava negro pela cor da pele, mas a gente nunca teve uma conversa de dizer "eu sou negro”, entendeu? ou, ou...é...tocar nessa questão. Tive uma que concluiu junto comigo a graduação no meu curso e tinha um outro colega que era de Engenharia Elétrica eu acho, que a gente andava juntos e ele também concluiu, com sucesso. E era excelente aluno. Era American Express. $O$ apelido dele porque era o cartão da época que que mais aprovava, então onde ele passar ou que ele fizesse era aprovado. Então ele era chamado de American Express.

[...]

Algum deles [orientandos] é negro... Não sei... Ah é, tenho um, tenho um. É porque são tantos. Quantos, eu tenho que contar, acho que são oito na pós né? acho que são 8, na pós. Um né... um... dois negros... [...] Fábio não. Ah Fábio, é pode ser. É... um moreno mais, moreno né? mestiço. Três. (grifos nossos) Sujeito D

Do meu departamento não tenho [colegas negras(os)], não tenho ninguém não. [...] No meu departamento não tem ninguém não negro, no círculo de amizade de outros departamentos que interagem com a gente, eu acho que talvez tenha no máximo dois, tem um com certeza, é ... um ou dois, também é raro.

[...]

Eu tenho cerca de 8 a 10 [orientandos]. [...] Não, negro mesmo não. Talvez seja um pouco, assim tem a característica, mas negro não. (grifos nossos) Sujeito I

A educação formal tem se constituído como importante elemento de mobilidade social, representação a aspiração das camadas populares (Machado, 2007). Ainda assim, conforme Machado (2007), a escolha da profissão docente pelos negros brasileiros nem sempre é uma questão de oportunidade, essa escolha é também forma de resistência e enfrentamento, ainda que isso nem sempre esteja tão óbvio, como podemos ver na fala do Sujeito G.

Rapaz, eu corri, eu corri, corri tanto, mas depois eu achei que era sina esse negócio, professor é...é... (...) quando eu estava saindo do ensino fundamental, é, a única certeza que eu tinha é que eu gostava de física e matemática, foi por isso que eu fiz eletrônica, (...) quando eu sai do curso de eletrônica eu continuava gostando de física e matemática, muito, e gostava de eletrônica naturalmente, só que eu não faria nem matemática nem fisica, porque eu achava que eu iria virar professor e ia ganhar muito mal (rsrsrs), então é, eu vou fazer como? vou virar professor, vou fazer o quê? (...). Sujeito G

Todavia, o "gostar de estudar" e as oportunidades de bolsas de estudo aparecem como determinantes para a continuidade da vida acadêmica. Além disso, os estímulos voltados aos estudos, advindos de diferentes pessoas e instituições, criam um gostar genuíno, como indicado em trechos de algumas falas, como as dos Sujeitos A e I. 
E ai as coisas foram vindo. Eu gostava de estudar, eu consegui as bolsas, consegui não sei o quê, entrei no mestrado na mesma leva e ai foi embora. Então assim, eu acho que é uma pessoa que tem que gostar de estudar, não pode se deixar influenciar pelo meio. Sujeito A

Na época que surgiu logo a oportunidade foi basicamente a bolsa mesmo, esse foi o principal atrativo. Mas assim, eu me identifiquei realmente pela área eu sempre tinha as melhores notas em disciplinas que eram relacionadas a Engenharia de Software e programação e desenvolvimento, normalmente as disciplinas que eram de programação eu me dava muito bem e de Engenharia de Software eu também gostava, essa terminou assim, uniu o útil ao agradável. Acho que a bolsa em si, apesar de o meu professor ser da área de Engenharia de Software e também trabalhar com isso, acho que a bolsa influenciou pouco [o interesse pela área], porque assim, era, era, meu papel era muito mais de programação, então eu construía coisas, era pouca a parte conceitual ai de Engenharia de Software mesmo. (grifos nossos) Sujeito I

As categorias "mudanças na vida pela educação" e "acesso à educação escolar" evidenciaram a importância dos estudos na vida das pessoas negras e seu poder transformador. Em geral, os entrevistados estudaram em algum momento em instituição privada, com ou sem bolsa: "fundamental foi escola privada, todo, e aí o ensino médio foi escola pública" (Sujeito G); "Privada, privada, sempre" (Sujeito D). O estudo foi fundamental para construção de perspectivas de ascensão social, como nos indicou o Sujeito A.

Mas quando eu comecei a entrar no ginásio e comecei a ver que eu poderia ter uma perspectiva de não ser empregada doméstica, né, porque enquanto eu era criança, o destino que eu via era ser babá, ser não sei o quê, como as crianças pobres, filhas de empregada na época, era o destino que elas seguiam. Sujeito A

Ainda assim, o aspecto financeiro e a necessidade de trabalhar para sustentar a família se mostraram alguns dos grandes obstáculos no avanço dos estudos - a necessidade de trabalhar e estudar simultaneamente, em muitos casos, retarda o avanço na vida acadêmica.

[...] eu trabalhava muito durante o periodo da graduação e da pós não é porque eu queria trabalhar muito, ninguém quer trabalhar de manhã, de tarde e de noite, ninguém que chegar e dormir na sala, eu dormia na sala quando eu tava fazendo meu curso, eu chegava, eu sentava na frente porque eu queria prestar atenção, mas eu ficava ali ohh....o ar condicionado batia em cima de mim, eu fazia assim (rsrsrs)... eu dormia, era impressionante, eu dormia na aula de [nome omitido], eleito o melhor professor, eu sentava lá e ficava assim...ai porque, eu tinha conta que eu tinha que pagar, não tinha, tinha que ajudar meus pais em casa. Sujeito G 
No tocante ao racismo e à discriminação, episódios dessa natureza parecem, em um primeiro momento, não estar na memória dos professores entrevistados, mas, com um pouco mais de atenção, eles narram diversas histórias que aos poucos vêm às suas mentes. Então, os episódios de racismo são descritos como acontecimentos que deixam fortes marcas negativas, conforme podem ser identificadas nas falas a seguir.

Teve a sogra de uma das patroas da minha mãe, que ela uma vez falou para minha mãe mesmo, falou "é, a sua filha é uma menina muito inteligente, mas é uma pena, porque ela é negra e não vai longe". [...] As pessoas, e assim, quando eu estudava ainda ginásio, essas coisas, muitas vezes assim, patrões, patroas da minha mãe ficavam falando "ah, porque que adianta você querer fazer uma coisa assim, você é negra, não vai para frente, eles não vão dar emprego para uma pessoa negra", né. Tinha muito essa coisa de é... porque no [cidade natal do entrevistado - omitido por questões éticas] tinha muito a história da boa aparência, né. Que quando você via na coisa por emprego "precisa de pessoas de boa aparência", você já entendia que negros eles não queriam. [...] Meus coleguinhas de classe moravam em... bairros que são bairros ricos. [...] Ai, vamos fazer trabalho na casa dos coleguinhas. Aí vou chegar na casa do coleguinha, o porteiro já "ó, porta dos fundos". Eu entrava pela porta dos fundos. (grifo nosso) Sujeito A

[...] essa coisa do mérito é um mérito questionável, a gente passa por muita coisa é... durante nosso percurso para poder estar aqui, todos os lugares que a gente vai, não é a academia, eu acho que na academia as coisas são mais escondidas, as pessoas elas tem um certo... né... de demonstrar, elas têm, elas têm de demonstrar, muitos casos, é velado, é velado, outros, outros onde as pessoas, as coisas são mais, mais diretas. Aqui outro dia eu fui parado pela polícia "- Cadê a droga?", aqui voltando pra casa, pois é, isso acontece. Eu já fui alugar uma casa e a menina olhou pra mim e disse "Você não tem condições de alugar minha casa”, acontece. Eu já cheguei no bar, o cara veio, me deu uma cerveja, o cara veio botou uma etiqueta com o preço da cerveja na garrafa, isso acontece e essas coisas assim, num é porque eu sou pobre simplesmente, porque pobre existem vários né... então assim, eu sou a favor completamente a gente precisa mudar e não é pra hoje, já perdeu muito tempo, a gente já perdeu muito tempo. Sujeito G

Ai ela disse "a secretária já me olhou de cima a baixo e ai eu falei para ela que eu tava vendo possibilidade de você vir de ter uma bolsa, de não sei o quê e ela já foi logo cortando". "Ah, sua filha não vai se dar bem aqui, porque o cursinho é muito puxado, porque precisa ter tido uma boa base no ensino fundamental e tal, porque não sei o quê", e minha mãe, "não, mas ela sempre foi muito boa aluna na escola", "ah, mas escola pública a senhora sabe como é que é" isso naquela época, quando escola pública ainda era muito boa. Mas na verdade o que minha mãe sentia: negro, pobre, aqui eu não quero. Sujeito A

Muitas atitudes de professores na época escolar não eram lidas como racismo pelos entrevistados, já na vida adulta alguns se deram conta de que foram submetidos a situações discriminatórias na escola por professores, como indicado pelo Sujeito D. 
Fui me lembrar... ainda no ensino o quê? fundamental... acho que fundamental II. Uma professora de português que isso ficou na minha cabeça... que eu chegava lá..ai ela ... ela gostava de mim assim porque eu sempre fui muito boa aluna... aquela menina né, muito bem comportada. Mas ela chegou assim e falou: "- Mas minha filha, sua mãe não penteia seu cabelo não é quando você vem?". Aí puxava meu cabelo assim pra amarrar pra ficar com o coquezinho todo comportado. Agora eu pensei assim: Nossa, acho que a mulher... ela avaliava assim essa menina tão boa aluna, mas... Entendeu né? Esse tipo de coisas, né?

\section{$[\cdots]$}

É isso, na graduação eu não lembro de nada explícito. Mas é quando a gente faz assim uma reflexão de algumas coisas, de algumas dificuldades, às vezes, talvez assim, um.. um acesso não tão direto a alguns professores. Aí depois de passado que eu começo a associar um pouquinho que talvez tenha sido um pouco de preconceito pela cor, mas nada explícito. Sujeito D

Os estereótipos atribuídos aos negros e à baixa representatividade na área limitam o olhar do outro em relação às suas competências e aptidões, com atitudes racistas e discriminatórias, como indicam os excertos a seguir. Vale lembrar que o "racismo velado é característica peculiar do racismo à brasileira que se projeta em todos os setores sociais em que os/as negros/as brasileiros convivem na sociedade" (Gomes, 2008, p. 45).

[...] já tive [contato com racismo e discriminação] depois como professor. Eu... já sim, teve aluno de sair da sala de aula, eu cheguei no primeiro dia, cheguei na sala ele, nessa época eu dava escola particular né, eu cheguei entrei, e o menino saiu, ele simplesmente saiu, foi procurar a coordenação, não queria ter aula comigo não, voltou, hoje é até meu amigo. (grifo nosso)

\section{Sujeito G}

[...] uma vez eu me lembro que eu fui ao <omitido> né. Porque eu tava com uns problemas estatísticos, uns experimentos de estatística que a gente tinha que fazer, então eu precisei ter consultoria de alguém. Ai alguém me deu um nome de um professor lá do <omitido> de estatística. Aí eu fui lá com a minha aluna e ele olhou para mim e falou "- Nossa! Não sabia que tinha um professor negro na Computação”. Sujeito A

Pois é eu não via isso com muitos problemas não, mas depois...é porque é algo muito velado eu acho, talvez. Então assim...hoje eu me questiono, que talvez muitos questionamentos ou algumas hã...como é que poderia dizer...é algumas barreiras ou algumas discordâncias de alguns colegas de algumas atitudes não sejam necessariamente pelas atitudes. Talvez tenha uma por trás uma rejeição tipo assim: poxa, mas essa mestiça, assim ou essa negra, sei lá, assim. Sabe uma desqualificação talvez do que venha né como resultado. Sujeito D

[...] você chegar nas conferências e olhar para um lado, olhar para o outro e é praticamente estranho no ninho né, isso me incomoda. Sujeito $\mathbf{G}$ 


\section{MAIS RESULTADOS: OS NÃO DITOS}

$\mathrm{O}$ contexto em que se formam os/as intelectuais negros/as é o da discriminação racial que desumaniza a população negra e a exclui da sociedade e desta forma tira-lhe o direito de acesso às condições básicas de melhor qualidade de vida. Gomes (2008, p. 35)

Os resultados encontrados dão a dimensão dos desafios vivenciados por negras e negros nas suas vidas pessoais até a chegada à academia. Nesta seção utilizaremos exclusivamente dados da entrevista do Sujeito A, por considerá-la(o), dada sua trajetória e contexto, ilustrativo do ser docente negro na pós-graduação em Computação.

Mas não foi só por isso. O Sujeito A apresentou com mais riqueza de detalhes a trajetória acadêmica e como o "reconhecimento de sua negritude" ocorreu, em meio à construção da "identidade branca" socialmente construída nos espaços educacionais pelos quais transitou, especialmente na universidade.

O sujeito A é uma mulher negra, a partir de agora tratada no feminino. Por meio de sua entrevista, com duração de 82 minutos (a mais longa dentre as cinco entrevistas realizadas), ela nos forneceu um rico material para estudo. A trajetória da professora através das suas relações no/com o meio do qual fazia/faz parte, da infância até a vida adulta, possibilitou um aprofundamento no estudo da construção de uma profissional que traz signos sociais nas suas características físicas que afetam diretamente a sua vida atualmente.

Angela Davis (2016) cita os marcadores que acentuam os preconceitos vivenciados por mulheres negras interseccionalizando gênero, raça e classe. Davis também relaciona aspectos do capitalismo e do sexismo, que, segundo ela, são condições estruturantes nas relações humanas, responsáveis por gerar formas combinadas de opressão. Há uma interação entre aspectos que se constituem "marcas de subordinação" dos sujeitos. Isso representa uma diferente vivência para cada sujeito de acordo com seu gênero, raça, orientação sexual, entre outros aspectos.

A trajetória da professora é cercada por esses marcadores. Oriunda de família pobre, ela passou sua infância na casa da patroa da mãe (doméstica), local em que também residia. Desenvolveu interesse pelos estudos e atribui isso à dedicação da 
mãe e à colaboração do filho da dona da casa, que percebeu que a então menina "levava jeito" para estudar.

Dentre as categorias utilizadas para o estudo, identificamos a evidência de algumas que nos levaram a analisar contradições pertencentes aos discursos da professora. Algumas dessas análises visam a contextualizar e interpretar para além do dado explícito na entrevista - denominamos não-ditos. Abaixo, apresentaremos algumas dessas discussões e análises.

Essa professora nos informou que não gosta de "ficar na mídia" acadêmica, prefere fazer seu trabalho na universidade, como professora e como pesquisadora, mas sem ficar em evidência. Isso nos faz lembrar que o "silêncio é uma estratégia para o enfrentamento da convivência difícil com a discriminação em seu cotidiano" (Machado, 2007, p. 115).

Alguns episódios de discriminação foram relatados pela entrevistada. Ela, quando criança, ouvia alguns adultos dizerem para sua mãe que era uma pena uma menina com potencial tão grande não chegar a lugar algum por ser negra. Em outro momento também ouviu alguém comentar que seu futuro estava destinado às atividades domésticas.

A esse respeito, a professora relata que (ela) e sua mãe trabalhavam em casa de pessoas muito ricas, cuja mentalidade era que filha de empregada deve crescer e ser empregada também.

Tal situação expressa o racismo e a estereotipação por parte desses que faziam parte do convívio da professora. Tal pensamento reproduz a lógica de que o sujeito negro ou negra está apto única e exclusivamente aos lugares de servidão, em vez dos "lugares de conhecimento".

Contrariando essas expectativas, ela concluiu a etapa do primário (ensino fundamental I). Quando foi para o ginásio (ensino fundamental II), teve a oportunidade de entrar em um cursinho de prestígio, com bolsa de estudos. A priori, ela queria estudar Letras e, por meio de um teste vocacional, soube que tinha aptidão para Engenharia e Matemática. Até o segundo ano do Ginásio, ela tinha a convicção de que faria algum curso na área de Línguas, mas acabou por escolher a Matemática e, mais tarde, migrou para a Computação. 
Nessa entrevista específica, a categoria “(não) percepção ou afetividade do desrespeito, preconceito e a discriminação" foi identificada em vários trechos da fala da professora. A impressão é que, à medida que a professora avança em suas conquistas acadêmicas, começa a não enxergar as formas de racismo ao qual está exposta. Ao ser indagada se em algum momento se sentiu discriminada por ser negra na universidade, ela diz: "Não... Isso realmente não. Na faculdade nem por parte de professores, nem por parte de colegas, nunca senti nada de discriminação".

Mas, em outro momento, ao ser questionada se tem contato com outros professores negros na instituição em que trabalha, evidencia-se a não percepção ou afetividade da desigualdade profissional (representatividade do negro na universidade), ainda que frequentemente "os professores negros sejam colocados à prova e tenham que mostrar suas condições intelectuais que nem sempre são bem vistas por todos" (Machado, 2007, p. 112):

Não. Aqui não. Por enquanto não. [suspensão de pensamento] E eu acho que na <instituição omitida $>$ deve ter lugar... Bom, eu vejo muito nas Artes tem muitos professores negros. [...] Ai ele [professor branco de outro departamento] também começou a perguntar, quanto tempo tá lá, não sei o quê, como é que veio, como é que não sei o quê... Eu realmente sou uma pessoa muito [...] Eu me considero uma pessoa meio tímida assim, fechada, né? Então assim, eu participo pouco das coisas na <instituição omitida $>$. Vou assim às reuniões, eventualmente e tal, mas muito pouco. Então assim, acho que a maioria das pessoas não me conhece. (grifos nossos)

Em relação à identificação da presença de negras(os) na pós-graduação da Computação, ela afirma haver poucos e demonstra perplexidade ao lembrar que fora do Brasil a presença de negros e negras nas faculdades de Computação é maior, como já citado: "E assim, é impressionante isso no Brasil porque você sai, você vai pros Estados Unidos, Inglaterra, onde você em princípio, vê que a discriminação é maior, mas tem muito mais alunos negros". Ou quando fala de sua experiência no exterior:

E ai eu entrei na sala e ele começou a conversar comigo naturalmente em [língua local, omitida por questões éticas], e ela não tava ainda. Ai ela chegou e começamos a falar em português. E ai ele falou assim: "ah, você fala português?" Eu disse, "ué, eu falo, eu sou brasileira.". ele "brasileira?", eu falei "é, por quê?", ele "até onde eu saiba todo brasileiro no Brasil é pobre, analfabeto, como é que você tá fazendo doutorado aqui?" aí eu "então..." (risos). Pois é, então assim, negros brasileiros não tinham não. As pessoas ficavam muito espantadas. (grifo nosso) 
Ainda assim, quando a pergunta versa sobre as cotas para negros na pósgraduação, ela classifica a política afirmativa como uma ação discriminatória:

$\dot{E}$, então. O coordenador de pós veio veio conversar comigo uma vez também. Então eu fui até numa reunião aqui na <instituição omitida>, por causa dessa história de cotas e tal. Bom, eu não sei se ações afirmativas se reduz às cotas, mas assim, em termos das cotas, eu não sou muito a favor. [...] Aliás muito não, eu não sou a favor, porque eu acho que as cotas são discriminatórias, assim, ao fim ao cabo. Porque você vai ficar com aquele carimbo, entendeu.

A professora justifica seu pensamento sobre cotas, afirmando que "isso deveria partir de dar uma educação básica boa, porque assim, o que me permitiu chegar aonde eu cheguei foi uma educação básica boa, né. Primário e principalmente ginásio científico."

Não obstante, podemos identificar que, em sua trajetória, o acesso à educação básica foi marcada por oportunidades como bolsas de estudo, auxílio financeiro de pessoas próximas ou conhecidas. Questionamos a similaridade dos efeitos que esses "incentivos" causaram para a sua trajetória em comparação com as oportunidades que também podem surgir a outro sujeito negro ou negra ao adentrar o espaço acadêmico por meio de ações afirmativas. Isso pode ser verificado na sua seguinte fala:

E ai eu fiz um cursinho preparatório. E esses cursinhos preparatórios em geral eram pagos. No <estado> na época tinham poucos e eles eram pagos. Mas eu consegui uma bolsa. Minha mãe conseguiu uma bolsa pra mim na época.

Apesar de possuir posicionamento contrário à política de cotas, a professora reconhece a desigualdade que pessoas negras estão suscetíveis. Ressaltamos que a desigualdade percebida pela professora lhe serve como argumento ao discurso favorável às ações afirmativas. A exemplo disso, ela afirma, na entrevista, que

[...] o governo brasileiro deve sim alguma coisa aos negros por causa da forma como foi terminada a escravidão. Que ele deixou, né? [...] Vocês não são mais escravos mas se virem. [...] nos outros países não foi assim, né? Mas aqui no Brasil foi. Eles não deram a menor condição das pessoas conseguirem se inserir na sociedade nem nada [...].

A professora, apesar de sua origem pobre, passou a vida em espaços pouco comuns, na sua época de formação, para pessoas com suas condições financeiras e raça. Isso talvez seja motivo da reprodução do discurso de meritocracia (YOUNG, 2017). A exemplo dos trechos em que ela afirma que seu contato com pessoas de sua 
faixa de renda é muito pouco, seus contatos estavam em sua maioria na classe média e "...eles achavam que eu era rica. Por causa da maneira de falar, da maneira de vestir, eles não conseguiam me associar com uma classe extremamente pobre."

\section{BREVE DISCUSSÃO}

Assim como na pesquisa de Machado (2007), os dados mostram que os professores não identificaram, ou tiveram dificuldade de identificar, ações discriminatórias ao longo de suas trajetórias. Em alguns casos, identificaram essas ações, mas com motivos parecidos indicavam não os enxergar. Afirmam, no entanto, saber que havia discriminação, preconceito e racismo em várias atitudes de colegas ou de professores, ao longo de sua trajetória e nos dias atuais em sua atividade profissional. Os sujeitos nem sempre têm nome, as agressões aparecem diluídas nas falas e nos cotidianos desses sujeitos, muitas vezes de modo dissimulado e socialmente aceito e comungado pelos seus pares.

Em alguns casos, há a mascaração e internalização da discriminação e do estereótipo branco ao se referir ao outro como "moreno", como mecanismo de tentar encaixá-lo em uma classificação racial, cujas cores de pele não são suficientes, nem puramente determinantes. Ainda assim, não consideramos que negras ou negros preferem ser rotulados como brancos. Segundo Gomes (2008), esse discurso faz parte das estratégias de dissimulação do racismo para justificar ideologia do branqueamento e da democracia racial.

Apesar disso, ao perceber e identificar essas atitudes discriminatórias e racistas, ainda que em pequenos gestos, comentários ou atitudes menos sutis, essas(es) professoras(es) desenvolvem mecanismos de resistência e enfrentamento. Alguns mais silenciosos, outros menos; alguns mecanismos mais introspectivos, outros mais ativos, o que gera desdobramentos que não lhe permitem a invisibilidade. Esse é o caso do Sujeito D, professora que alcançou o prestígio acadêmico institucional a partir das suas ações mais "humanizadas" para com os estudantes, suas realidade e necessidades.

Pela trajetória e discurso dos sujeitos desta pesquisa, a humanização dos/nos processos acadêmicos parece ser um processo natural de enfrentamento ao racismo e à discriminação pelos pares. Mas, ainda assim, a discussão sobre esses problemas 
tende a ficar obscurecida pelo "embranquecimento" acadêmico, fortalecido pela "naturalização" do racismo.

\section{CONSIDERAÇÕES FINAIS}

Há um longo caminho a se fazer no sentido da construção de conhecimentos históricos, antropológicos e sociotécnicos sobre a Ciência da Computação, sobretudo no tocante à participação de negras e negros.

Nesse sentido, esta pesquisa piloto identificou algumas histórias de negras e negros atuantes como professoras e professores da pós-graduação em Ciência da Computação. O principal objetivo da pesquisa foi descortinar trajetórias de sujeitos cuja formação se deu em uma época em que não havia largos debates sobre ações afirmativas na graduação, tampouco na pós-graduação em Ciência da Computação.

Sabemos que ainda há muito o que investigar e, inclusive, relacionar com o conhecimento científico construído no campo de estudos de raça no Brasil e no exterior. Ainda assim, acreditamos que os dados coletados nesta pesquisa foram capazes de oferecer insights sobre possíveis problemáticas geradoras de pesquisas no campo das desigualdades raciais na Ciência da Computação. Esta pesquisa acumulou muitos dados, alguns não apresentados neste artigo, que merecem ser melhor explorados qualitativamente.

Muitas questões surgem a partir dessa pesquisa piloto, tais como:

- Quais são os desafios para promoção da equidade de gênero e raça/etnia na Ciência da Computação?

Qual é o quantitativo de negros e negras nos programas de pós-graduação em Computação no Brasil?

Como foram as trajetórias de vida acadêmica dessas pessoas?

Qual é o perfil e como se dá a atuação de negros e negras no quadro docente de programas de pós-graduação em Computação?

Como eles e elas se veem enquanto negros e negras em áreas predominantemente brancas e elitistas? 
Por quais desafios passaram para assumir e manter o lugar como pesquisador em um programa de pós-graduação em Ciência da Computação?

Além disso, acreditamos que articulação entre dados qualitativos e quantitativos (como os dados de cor/raça e gênero dos professores atuantes na pósgraduação brasileira em Ciência da Computação cadastrados na Plataforma Lattes) pode ser útil para futura complementação desta pesquisa com produção de novas inferências. Isso poderia oferecer uma visão mais abrangente e geral sobre essas questões, possibilitando teorizar-se sobre o tema no âmbito da Ciência da Computação.

\section{AGRADECIMENTOS}

Agradecemos à Ford Foundation e a toda gentil e atenciosa equipe da Fundação Carlos Chagas pelo suporte e provimento de recursos para financiamento desta pesquisa, por meio do Concurso de Pesquisa Negras e Negros nas Ciências. Ao Instituto de Matemática e Estatística da Universidade de São Paulo (IME/USP) e ao Grupo de Pesquisa e Extensão em Informática, Educação e Sociedade - Onda Digital, pelo suporte técnico oferecido para a concretização das atividades relacionadas à pesquisa. Nosso agradecimento especial a todas(os) professoras(es) e pesquisadoras(es) que colaboraram conosco nesta pesquisa e que se dispuseram a nos contar um pouco da sua história.

\section{REFERÊNCIAS}

ARAÚJO, C. Potencialidades e limites da política de cotas no Brasil. Rev. Estud. Fem., Florianópolis, v. 9, n. 1, p. 231-252, 2001.

BEVILAQUA, C. B. The institutional life of rules and regulations: ten years of affirmative action policies at the Federal University of Paraná, Brazil. Vibrant, Virtual Braz. Anthr., Brasília, v. 12, n. 2, p. 193-232. dez. 2015.

BITTAR, M.; ALMEIDA, C. E. M. Mitos e controvérsias sobre a política de cotas para negros na educação superior. Educ. rev., Belo Horizonte, n. 28, p. 141-159, dez. 2006.

DAVIS, A. Mulheres, raça e classe. São Paulo: Boitempo, 2016.

DOMINGUES, P. Movimento Negro Brasileiro: alguns apontamentos históricos. Tempo. v. 12, n. 23, p. 100-122, 2007.

FERREIRA, R. F. Afrodescendente: identidade em construção. São Paulo: EDUC, 2000. 
GOMES, A. P. S. Trajetória de vida de Intelectuais Negros(as): contribuição para a Educação das Relações Étnico-raciais. Dissertação (Mestrado em Educação) - Universidade Federal de São Carlos, São Carlos, 2008.

INSTITUTO BRASILEIRO DE GEOGRAFIA E ESTATÍSTICA - IBGE. Pesquisa nacional por amostra de domicílios: sintese de indicadores 2015. Coordenação de Trabalho e Rendimento. Rio de Janeiro: IBGE, 2016. 108 p. Disponível em: $<$ https://biblioteca.ibge.gov.br/visualizacao/livros/liv98887.pdf $>$. Acesso em: 27 jul. 2018.

INSTITUTO DE PESQUISA ECONÔMICA E APLICADA - IPEA. Políticas Sociais: acompanhamento e análise. Anexo Estatístico. Brasília, n. 22, 2014. 40 p. Disponível em: $<\mathrm{http}$ //www.ipea.gov.br/portal/images/stories/PDFs/politicas_sociais/140930_bps22_anexo. pdf>. Acesso em: 29 mar. 2016.

LIMA, N. R. L. B. As mulheres nas ciências: o desafio de uma passagem... a passagem do privado para o público. In: COSTA, A. A. A.; SARDENBERG, C. M. B. (Org.). Feminismo, Ciência e Tecnologia. Salvador: REDOR/NEIM-FFCH/UFBA, 2002. p. 51-65.

MACHADO, L. H. A. Professores negros, experiências de discriminação, de racismo e pedagogias anti-racistas. Dissertação (Mestrado em Educação) - Universidade Federal de São Carlos, São Carlos, 2007.

MAIA, M. G. B. Políticas de acesso à educação superior: o sistema de cotas para negros. Dissertação (Mestrado em Educação) - Pontifícia Universidade Católica do Paraná, Curitiba, 2007.

MARGOLIS, J.; ESTRELlA, R.; GOODE, J.; HOLME, J.J.; NAO, K. Stuck in the Shallow End: Education, Race, and Computing. EUA, MIT Press, 2017.

OLIVEIRA, M. A.; de ROSE, T. M. S. Componentes da identidade étnica de jovens universitários brancos, pardos e pretos. In: SILVA, P. B. G.; MORAIS, D. S. (Org.). Ações Afirmativas: perspectivas de estudantes da reserva de vagas. São Carlos: EDUFScar, 2015. p. 81-90.

PUC-RIO. Departamento de Informática. História, [2000]. Disponível em http://www.inf.puc-rio.br/departamento/historia/. Acesso em: 27 jul. 2018.

ROSEMBERG, F. Ação afirmativa na pós-graduação: o Programa Internacional de Bolsas da Fundação Ford na Fundação Carlos Chagas. São Paulo: FCC/SEP, 2013. (Coleção Textos FCC, 36).

SILVA, S. R.; NEGRÃO, M. Normatividade, políticas públicas educacionais e a questão racial no Brasil. Rev. Bras. Estud. Pedagog., Brasília, v. 93, n. 235, p. 864-882, dez. 2012.

TAKAHASHI, F.; SALDAÑA, P.; SOARES, M. Cotista tem nota boa na universidade, mas recua em cursos com matemática. Folha de São Paulo, São Paulo, 10 dez. 2017. Disponível em: https://goo.gl/XzH6td. Acesso em: 10 dez. 2017.

UNIVERSIDADE FEDERAL DA BAHIA - UFBA. Instituto de Matemática. Histórico. [2018a]. Disponível em http://ime.ufba.br/index.php/diretoria/. Acessado em: 28 jul. 2018.

Instituto de Matemática. Site do curso de Ciência da Computação, [2018b].

Disponível em http://www.bcc.ufba.br/. Acesso em: 27 jul. 2018. 
UNIVERSIDADE ESTADUAL DE CAMPINAS - UNICAMP. História da computação na Unicamp, [2000?] Disponível em: $<$ https://www.ic.unicamp.br/sobre/institucional/historia/ic>. Acesso em: 27 jul. 2018.

YOUNG, M. The Rise of meritocracy. London: Routledge (Taylor \& Francis), 2017. 